УДК 636.7:619:616.995.428-07

(C) 2014

Свстаф'єва В. О., доктор ветеринарних наук,

Гаврик К. А., здобувач

(науковий керівник - доктор ветеринарних наук В. О. Свстаф'єва)

Полтавська державна аграрна академія

\title{
УДОСКОНАЛЕННЯ МЕТОДІВ ЗАЖИТТЕВОЇ ДІАГНОСТИКИ САРКОПТОЗУ, ОТОДЕКТОЗУ ТА ДЕМОДЕКОЗУ СОБАК
}

\section{Рецензент - доктор ветеринарних наук М. В. Скрипка}

Представлені результати визначення показників діагностичної ефективності зажиттєвих методів діагностики акарозів собак, а саме: саркоптозу, отодектозу й демодекозу. Порівнювали методи Приселкової та Алфімової, а також удосконалений нами спосіб. Встановлено, щчо запропонований удосконалений спосіб діагностики саркоптозу, отодектозу та демодекозу собак має вищу діагностичну ефективність (на 5-40\%), аніж загальновідомі методи, а також не потребує значних затрат часу, водночас забезпечуючи високий ступінь просвітлення кірочок $i$ чіткість отриманого матеріалу.

Ключові слова: собаки, саркоптоз, отодектоз, демодекоз, інвазія, зажиттєві методи діагностики, ефективність.

Постановка проблеми. Серед хвороб домашніх непродуктивних тварин на урбанізованих територіях особливе місце займають акарози $[1,5]$. Акарози - це паразитарні захворювання, що зумовлені кліщами підкласу Acarina, ряду Acariformes. Акариформні, або справжні кліщі, значно поширені в усьому світі. Це майже дві третини усіх відомих кліщів, із-поміж яких є як вільноживучі, так і паразитичні види [2].

Для ветеринарної дерматологічної практики м'ясоїдних тварин найбільше значення мають такі акарози як саркоптоз, отодектоз та демодекоз [8]. Найчастіше хвороби уражують собак i мають значне поширення в багатьох європейських країнах, у тому числі в Україні $[7,9]$, через удосконалення відомих методів діагностики акарозів собак залишається актуальним питанням сьогодення.

Аналіз основних досліджень і публікацій, у яких започатковано розв'язання проблеми. Остаточний діагноз на акарози встановлюють комплексно, враховуючи епізоотологічні дані, анамнез і клінічну картину. Основною підставою для встановлення діагнозу щодо захворювання тварин на акарози є результати лабораторних досліджень, зокрема мікроскопії відповідного матеріалу (зіскрібків шкіри, кірочок) на наяв- ність кліщів, личинок або їх яєць [6].

Існуючі нині методики поділяються на мортальні (виявлення мертвих кліщів) і вітальні (виявлення живих кліщів, личинок та яєць). Із мортальних методів у виробничих умовах найширше застосовується метод компресорного дослідження з використанням розчину гідроксиду калію, натрію та ін. [4]. Методика вивчення живих акариформних кліщів включає застосування будь-яких розчинів, що не діють згубно на паразитів (метод Г. З. Шика, Д. О. Приселкової, А. В. Алфімової та ін.) [3].

Аналізуючи наведені вище дані літератури можна зазначити, що, незважаючи на значну кількість різних способів обробки дослідного матеріалу, проблема отримання його більшої прозорості залишається актуальною.

Мета і завдання досліджень. Метою досліджень було удосконалення вітальних методів діагностики саркоптозу, демодекозу та отодектозу собак.

У завдання входило визначення ефективності відомих вітальних методів та удосконаленого способу діагностики акарозів собак.

Матеріал і методи досліджень. Дослідження проводилися упродовж літньо-осіннього періоду 2014 року на базі Кременчуцької міської державної лабораторії ветеринарної медицини і лабораторії паразитології кафедри паразитології та ветеринарно-санітарної експертизи Полтавської державної аграрної академії.

Для визначення ефективності відомих методів та удосконаленого способу було вивчено 50 зіскрібків від хворих тварин (14 - від собак, хворих на демодекоз, 17 - від хворих на отодектоз і 19 - хворих на саркоптоз).

За підозри на саркоптоз та демодекоз збирали глибокі зіскрібки скальпелем до появи сукровиці на межі між ураженою та зовнішньо здоровою шкірою не менше, ніж із 2-3 місць, а за підозри на отодектоз для дослідження відбирали кірочки зі шкіри внутрішньої поверхні вушних раковин. Дослідний матеріал від кожної собаки досліджу- 


\section{ВЕТЕРИНАРНА МЕДИЦИНА}

вали трьома різними способами:

- спосіб Приселкової;

- спосіб Алфімової;

- удосконалений спосіб.

Враховували час, витрачений на підготовку матеріалу для дослідження (хвилин); середню кількість кліщів у зіскрібку; ступінь просвітлення кірочок та чіткість отриманого матеріалу після його обробки.

Статистичну обробку результатів експериментальних досліджень проводили шляхом визначення середнього арифметичного (M) та його похибки (m).

Результати дослідження. Отримані результати досліджень наведені в таблиці 1.

Як бачимо, за даними таблиці 1 найбільшу діагностичну ефективність отримали в разі застосування удосконаленого способу. Так, за саркоптозу собак середня кількість кліщів, яких виявляли у матеріалі, становила 2,57 $\pm 0,17$ екз., отодектозу - 1,76 $\pm 0,21$, демодекозу - 1,71 $\pm 0,12$ екз. (усього 2,06 $\pm 0,11$ екз.).

Меншу діагностичну ефективність показав спосіб Алфімової (з додаванням води й наступним підігріванням): за саркоптозу середня кількість виявлених кліщів у матеріалі дорівнювала $2,42 \pm 0,15$ екз., за отодектозу $-1,64 \pm 0,17$, за демодекозу - 1,71 $\pm 0,12$ екз. (усього $1,96 \pm 0,10$ екз.).
Найменшу діагностичну ефективність у випадку акарозів собак реєстрували під час застосування способу Приселкової (з використанням підігрівання). У разі саркоптозу у дослідному матеріалі виявляли $1,68 \pm 0,17$ екз. живих кліщів, за отодектозу цей показник становив 1,05 $\pm 0,20$ екз., у випадку демодекозу - 0,85 $\pm 0,20$ екз. (усього 1,24 $\pm 0,11$ екз.).

Враховуючи показники витраченого часу на підготовку відібраного матеріалу від інвазованих собак для мікроскопічного дослідження, найбільшу ефективність показав удосконалений спосіб (від однієї до двох хвилин). Використовуючи 3 діагностичною метою вітальних способів Приселкової та Алфімової, витрачено більше часу на дослідження матеріалу (12-15 та 15 хв відповідно).

Водночас, високий ступінь просвітлення кірочок і чіткість отриманого матеріалу за мікроскопічного дослідження отримували під час використання удосконаленого способу.

Спосіб Алфімової призводив до високого ступеню просвітлення кірочок, однак чіткість отриманого матеріалу була слабкою, що знижувало діагностичну ефективність даного методу. У разі використання способу Приселкової кірочки не просвітлювалися, що призводило до недостатньої чіткості матеріалу й зниження діагностичної ефективності.

\section{1. Порівняльна ефективність вітальних способів дослідження собак}

у випадку саркоптозу $(n=19)$, отодектозу $(n=17)$ та демодекозу $(n=14)$

\begin{tabular}{|c|c|c|c|c|}
\hline Спосіб дослідження & Інвазія & 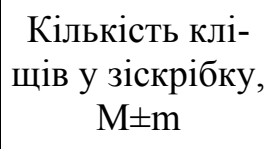 & $\begin{array}{c}\text { Час, витрачений на } \\
\text { підготовку матеріалу, } \\
\text { хвилин }\end{array}$ & $\begin{array}{c}\text { Просвітлення } \\
\text { кірочок / чіткість }\end{array}$ \\
\hline \multirow{4}{*}{ Приселкової } & саркоптоз & $1,68 \pm 0,17$ & \multirow{4}{*}{$12-15$} & \multirow{4}{*}{$\begin{array}{c}\text { не відбувається / } \\
\text { слабка чіткість }\end{array}$} \\
\hline & отодектоз & $1,05 \pm 0,20$ & & \\
\hline & демодекоз & $0,85 \pm 0,20$ & & \\
\hline & усього & $1,24 \pm 0,11$ & & \\
\hline \multirow{4}{*}{ Алфімової } & саркоптоз & $2,42 \pm 0,15$ & \multirow{4}{*}{15} & \multirow{4}{*}{$\begin{array}{l}\text { відбувається / } \\
\text { слабка чіткість }\end{array}$} \\
\hline & отодектоз & $1,64 \pm 0,17$ & & \\
\hline & демодекоз & $1,71 \pm 0,12$ & & \\
\hline & усього & $1,96 \pm 0,10$ & & \\
\hline \multirow{4}{*}{ Удосконалений } & саркоптоз & $2,57 \pm 0,17$ & \multirow{4}{*}{$1-2$} & \multirow{4}{*}{$\begin{array}{c}\text { відбувається / } \\
\text { висока чіткість }\end{array}$} \\
\hline & отодектоз & $1,76 \pm 0,21$ & & \\
\hline & демодекоз & $1,71 \pm 0,12$ & & \\
\hline & усього & $2,06 \pm 0,11$ & & \\
\hline
\end{tabular}




\section{ВЕТЕРИНАРНА МЕДИЦИНА}

Отже, запропонований удосконалений спосіб зажиттєвої діагностики саркоптозу, отодектозу та демодекозу собак відноситься до вітальних методів діагностики акарозів і має вищу діагностичну ефективність (на 5-40 \%) порівняно із загальновідомими способами.

\section{Висновки:}

1. Запропонований спосіб зажиттєвої діагностики саркоптозу, отодектозу та демодекозу собак

\section{БІБЛІОГРАФІЯ}

1. Белху T. Н. Эпизоотология и лечение демодекоза собак в условиях мегаполиса (на примере г. Москвы) : автореф. дисс. на соиск. уч. степ. канд. вет. наук : спец. 03.00.19 / Т. Н. Белху. M., 2000. - 19 c.

2. Василевич Ф. И. Демодекоз собак / Ф. И. Василевич // Болезни мелких животных. - М., 1992. C. 140-147.

3. Воличев A. Н. Эпизоотология основных паразитов плотоядных в условиях города Москвы / А. Н. Воличев // Тр. ВИГИС. - М., 2003. - Т. 39. C. 55-63.

4. Галат В. Ф. Короста свиней / В. Ф. Галат, О. О. Шевцов. - К. : Урожай, 1974. - 71 с.

5. Добычин Н. И. Изучение наиболее эффектив- відноситься до вітальних методів діагностики акарозів тварин.

2. Удосконалений спосіб має вищу діагностичну ефективність (на 5-40\%), порівняно $з$ методами Приселкової та Алфімової.

3. Запропонований спосіб діагностики акарозів собак не потребує значних затрат часу i забезпечує високий ступінь просвітлення кірочок.

ных методов диагностики чесотки домашних животных / Н. И. Добычин // Советская ветеринария. - 1940. - №12. - С. 12-15.

6. Дубинин В. Б. Чесоточные клещи / В. Б. Дубинин. - М. : Советская наука, 1954. - 172 с.

7. Майборода E. A. Арахноэнтомозы домашних животных Украины и Юга России / Е. А. Майборода // Наукові досягнення в галузі ветеринарної медицини : зб. матеріалів наук.-практ. конф. молодих вчених. - Х., 1997. - С. 32-33.

8. Медведев К. С. Болезни кожи собак и кошек / К. С. Медведев. - К. : Вима, 1999. - 152 с.

9. Паразитология и инвазионные болезни животных / [М. Ш. Акбаев, А. А. Водянов, Н. Е. Косминков и др.]. - М. : Колос, 1998. - 743 с. 